\title{
Pandemic shows deep vulnerabilities
}

\author{
Molly D. Anderson ${ }^{1}$
}

Accepted: 29 April 2020 / Published online: 11 May 2020

(c) Springer Nature B.V. 2020

The coronavirus pandemic didn't create new problems in the US food system, but it exposed deep inequities and dysfunction that were already there. Many people are praying that we return to "normal" as soon as possible; but our vulnerability opens a moment of opportunity to transform this food system that benefits mostly wealthy consumers, shareholders, and executives.

Twelve years ago, I argued in Agriculture \& Human Values (Anderson, 2008) for a rights-based food system that would respect, protect and fulfill the human rights of farmers (e.g., fair prices for what they produce and adequate compensation for full-time work); workers (e.g., decent working conditions and living wages); rural communities (e.g., a healthy environment); and the people who buy and consume products from US farms (e.g., adequate healthy food for all). Twelve years later, conditions for those working in the food system have only gotten worse. The rapacious pillage of territory that belongs to other people through land-grabs and exploitation of workers from other countries have proceeded at an accelerated pace so that wealthy people in the US can eat whatever they want and pay artificially low prices for food. The US is even farther away from ensuring economic, social and cultural rights for every person. The coronavirus has illuminated the dangers of ignoring human rights and failing to protect the commons of public health, while the concurrent climate emergency has shown us that humans are not "essential workers" from the perspective of the planet and its other inhabitants.

What can we do to move quickly toward a food system transformed? First, we must resist the calls to prop up "business as usual" (or as it used to be): no bailouts for huge food industries such as exploitative meatpackers or the petroleum and coal industries that have decimated our beautiful world.

This article is part of the Topical Collection: Agriculture, Food \& Covid-19.

Molly D. Anderson

mollya@middlebury.edu

1 Middlebury College, Middlebury, VT 05753, USA
Under neoliberalism, the biggest industries have come to feel entitled to their wealth, even though they don't abide by a social contract to use that wealth for the public good. They are lined up at the federal trough, ready to shove aside small business, farmers and cooperatives and citizens.

Second, we must use stimulus funds not only to get people back on their feet but to create meaningful jobs in lifeenhancing work: building the infrastructure for high-speed electric trains, renewable energy facilities, growing food, the arts. We should take a lesson from the original New Deal and hire artists to document, inspire and create a vision of renewal.

Third, we need to extinguish for good the ugly inequity of healthy food for the wealthy and junk food for poor people. All people deserve healthy food, produced in sustainable ways that don't mortgage our future. This means ensuring that every school child receives nutritious food for every meal, but also that anyone who is out of work, incapacitated, mentally ill or otherwise vulnerable has the same. We have made a good start with Supplemental Nutrition Assistance and the National School Lunch and Breakfast Programs, but such programs cannot be held hostage to Congressional or Presidential mean-spiritedness. And these programs can purchase all or nearly all of their food from local farmers using sustainable farming practices, to strengthen city-region links and support struggling farmers.

Fourth, we need to get serious about transforming agricultural practices. We simply cannot continue supporting an industrial agriculture that is destroying soil fertility with synthetic fertilizers, overproducing commodity crops and driving down prices that farmers receive, exterminating insects and songbirds, contaminating soil and water, and tying up land in monocultures. Anyone who wants to raise food for her family should have access to fertile land and other resources needed; knowledge about agroecology (including organic, regenerative and other diversified farming practices) should be widely shared; and farmers should be supported in making a transition to agroecological practices.

These are all measures that should have and could have been implemented long ago. Our lands, waters and people 
would be much better off and more resilient had that happened. We're very late in making changes for the better, but all the more reason to get started on realizing the human rights of everyone in this country.

\section{Reference}

Anderson, Molly D. 2008. Rights-based food systems and the goals of food systems reform. Agriculture \& Human Values 25: 593. https ://doi.org/10.1007/s10460-008-9151-z.
Publisher's Note Springer Nature remains neutral with regard to jurisdictional claims in published maps and institutional affiliations.

Molly D. Anderson is the William R. Kenan Jr. Professor of Food Studies at Middlebury College, where she teaches and directs the Food Studies Academic Program. She is interested in food system resilience and forging links between efforts to create more sustainable food systems at multiple scales. 